\title{
Comparison of lipid components, iron and zinc levels in chicken and quail eggs available on the market
}

\author{
Małgorzata Czerwonka ${ }^{1, *}$, Agnieszka Białek ${ }^{1,2}$, Dorota Skrajnowska ${ }^{1}$ and Barbara Bobrowska-Korczak ${ }^{1}$ \\ 1 Affiliation 1; Department of Bromatology, Faculty of Pharmacy with the Laboratory Medicine Division, \\ Medical University of Warsaw, 1 Banacha, 02-097 Warsaw, Poland, bromatologia@wum.edu.pl \\ 2 Department of Biotechnology and Nutrigenomics, Institute of Genetics and Animal Biotechnology, Polish \\ Academy of Sciences, Postępu 36A Jastrzębiec, 05-552 Magdalenka, Poland, a.bialek@ighz.pl \\ * Correspondence: malgorzata.czerwonka@wum.edu.pl
}

\begin{abstract}
All over the world birds' eggs are an important and valuable component of the human diet. The study aimed to compare the content of lipid components and their nutritional value as well as iron and zinc levels in chicken and quail eggs commonly available on the market. In egg lipids, unsaturated acids were dominated, especially oleic acid, the content of which was about $40 \%$ of total fatty acids (TFA). Linoleic acid was the major polyunsaturated fatty acid. Compared to other products of animal origin, eggs were characterized by favourable values of lipid quality indices, especially index of atherogenicity, thrombogenicity and hypocholesterolemic to hypercholesterolemic ratio. In the present study, no differences in the content of tested nutrients between eggs from different production methods (organic, free-range, barn, cages), as well as inter-breed differences were noticed. Cluster analysis showed that eggs enriched in n3 PUFA (according to producers' declaration) differ from other groups of chicken eggs. However, only in eggs from one producer, the amount of EPA and DHA exceed $80 \mathrm{mg}$ per $100 \mathrm{~g}$, entitling to use the nutrition claim on the package. Quail eggs differed from chicken eggs in FA profile; they also had much higher iron and cholesterol levels.
\end{abstract}

Keywords: chicken eggs, quail eggs, fatty acids, iron, zinc, cholesterol

\section{Abbreviations:}

AA - arachidonic acid; AI - index of atherogenicity; ALA - $\alpha$-linolenic acid; B - Barn chicken eggs; C - eggs from caged hens; DFA - hypocholesterolaemic fatty acids; DHAdocosahexaenoic acid; E - chicken eggs from ecological production; EPA - eicosapentaenoic acid; F - free range chicken eggs; FA - fatty acids; FLQ - flesh-lipid quality index; GL - Green-legged partridge eggs; GLA - $\gamma$-linolenic acid; H/H - hypocholesterolemic to hypercholesterolemic ratio; LA - linoleic acid; MUFA - monounsaturated fatty acids, N3 - chicken eggs with an increased content of n3 fatty acids; OFA - hypercholesterolaemic fatty acids; OL - oleic acid; PUFA - polyunsaturated fatty acids; Q - Partridge quail eggs; SFA - saturated fatty acids; TFA - total fatty acids; TI - Index of thrombogenicity.

\section{Introduction}

Bird eggs have always been an important and valuable component of the human diet. The consumption of eggs depends on various factors such as economic, cultural, religious and habits of feed. However, all over the world, they are perceived as nutritious, easily digestible, and delicious meals ingredient [1,2].

In the 1960s, it was recommended to limit the consumption of eggs due to the high content of cholesterol, which was supposed to promote hypercholesterolemia in the body [3]. This view became deeply ingrained in consumers thoughts. Today it is known that die- 
tary cholesterol does not affect the levels of low-density lipoproteins in the body. The most hypercholesterolemic/atherogenic effect is related to saturated fatty acids [4]. The unsaturated fatty acids that dominate egg fat have the opposite effect. Furthermore, recent studies on egg consumption demonstrate that eating those products daily does not alter LDL levels and can improve postmeal metabolic responses [5]. The profile of fatty acids in the diet has a significant impact on the body's lipid balance. In addition to fatty acids and cholesterol, the lipids of eggs include choline, fat-soluble vitamins, carotenoids [6]. A whole egg contains many valuable nutrients and bioactive ingredients: wholesome protein, most vitamins, and minerals, including iron and zinc [7]. Eggs are a great alternative to meat in the diet.

There are several product groups on the egg market. The most popular is the division into eggs obtained from various species of birds. All over the world, chicken eggs (Gallus domesticus) are the most popular, but also eggs of quail, duck, turkey, and other species are presented on the market [8]. In the European Union, hen eggs are classified in terms of weight and the production method. Organic eggs marked on the shell are number 0 , free-range eggs have number 1 , barn eggs 2, and cage eggs 3 [9]. There are also premium products on the market; eggs from less common breeds (e.g., Green-legged partridge) or enriched with selected vitamins, minerals or other bioactive ingredients [10]. Studies showed that the nutritional value of birds' eggs depends on many factors, such as the species and breed of animals from which the eggs were obtained, the production method and the type of feed [6]. Most of the research, however, was conducted under controlled conditions. There are much fewer studies that evaluated market products.

The study aimed to compare the content of lipid components and their nutritional value as well as iron and zinc levels in chicken and quail eggs commonly available on the market. Because, the amount of lipids in egg white usually does not exceed $0.2 \%$ [8], this study was limited to the nutritional composition of eggs yolk.

\section{Materials and Methods}

\subsection{Research material}

The research material comprised six groups of chicken eggs and quail eggs available on the Polish market. The groups were as follows:

- chicken eggs from organic production (E)

- free range chicken eggs $(F)$

- barn chicken eggs (B)

- chicken eggs from caged hens (C)

- chicken eggs with an increased content of n3 fatty acids (N3) (according to producers' declaration / nutrition claim on the package)

- chicken eggs from Green-legged partridge (GL)

- partridge quail eggs $(Q)$

The packaging of eggs from the first five groups lacked the indication of the breed of hens from which the eggs were obtained. Laying hens breeds predominating in the region are Rhode Island Red and Leghorn. Characteristic of examined egg samples; the weight parameters of all groups of eggs are presented in Table 1. In each group there were 8 brands (producers) evaluated. Three eggs were randomly collected from each package (brand) and separate analyses were performed for each egg $(n=3 \times 8=24$ per group). Six eggs were collected from each quail egg pack. Due to the small size, three yolks were combined into one sample $(n=6 / 3 \times 8=16)$. 


\subsection{Analytical methods}

\subsubsection{Fat content determination}

Fat content in egg yolk samples was determined gravimetrically after three-times extraction with a mixture of chloroform/methanol (v/v 2:1) and solvents evaporation under a stream of nitrogen, according to the procedure described by Folch et al. [11].

\subsubsection{Fatty acids analysis}

Fatty acid concentration and profile was determined by gas chromatography with flame ionization detector after methylation procedure was based on method described by Białek et al. [12]. To extracted egg yolk fat (about $20 \mathrm{mg}$ ) $1 \mathrm{~mL}$ of $0.5 \mathrm{M} \mathrm{NaOH}$ in methanol was added and heated in $80^{\circ} \mathrm{C}$ for 15 minutes. Then $1 \mathrm{~mL}$ of BF3 solution in methanol $(14 \% \mathrm{w} / \mathrm{v})$ was added and again heated in $80^{\circ} \mathrm{C}$ for 15 minutes. Then extraction of FAME was performed by adding $1 \mathrm{~mL}$ of saturated solution of $\mathrm{NaCl}$ in water and $1 \mathrm{~mL}$ of hexane and shaking. After phase separation the hexane layer was transferred to $2 \mathrm{~mL}$ vial and injected on the column.

Analyses were performed on a gas chromatograph with flame ionization detector (Shimadzu GC-17A, Kyoto, Japan). Chromatographic separations were conducted on a capillary column SGE BPX70 (60 m / 0,25 mm ID / film thickness 0,20 $\mu \mathrm{m}$; Ringwood, Australia). Helium was used as the carrier gas (flow: linear velocity at $0.9 \mathrm{~mL} \mathrm{~min}^{-1}$ ), the injection was $1 \mu \mathrm{L}$, the split has been set to 10 . The injector was heated to $250^{\circ} \mathrm{C}$, the detector to $270^{\circ} \mathrm{C}$. The temperature program was as follows: initial temperature $-140^{\circ} \mathrm{C}$ for $1 \mathrm{~min}$, increase by $20^{\circ} \mathrm{C}$ per min to $200^{\circ} \mathrm{C}$, hold for $20 \mathrm{~min}$, increase by $5^{\circ} \mathrm{C}$ per min to $220^{\circ} \mathrm{C}$, hold for $25 \mathrm{~min}$. FAME standards (Supelco 37Component FAME Mix, Sigma, St. Louis, MO, USA) were used to identify the FA present in the samples.

Based on the percentage of fatty acids, the following indices of lipid quality were calculated $[13,14]$ :

a. Flesh-lipid quality (FLQ)

$\mathrm{FLQ}=\mathrm{EPA}+\mathrm{DHA}$

b. Index of atherogenicity (AI):

$\mathrm{AI}=[(4 \times \mathrm{C} 14: 0)+\mathrm{C} 16: 0] /(\mathrm{MUFA}+\mathrm{n} 3 \mathrm{PUFA}+\mathrm{n} 6$ PUFA $)$

c. Index of thrombogenicity (TI):

$\mathrm{TI}=[\mathrm{C} 14: 0+\mathrm{C} 16: 0+\mathrm{C} 18: 0] /[(0.5 \times$ MUFA $)+(0.5 \times \mathrm{n} 6$ PUFA $)+(3 \times \mathrm{n} 3$ PUFA $)+(\mathrm{n} 3$ PUFA

/ n6 PUFA)]

d. Hypercholesterolaemic fatty acids (OFA):

OFA $=\mathrm{C} 14: 0+\mathrm{C} 16: 0$

e. Hypocholesterolaemic fatty acids (DFA):

DFA = C18:0 + MUFA + PUFA

f. Hypocholesterolemic/hypercholesterolemic ratio $(\mathrm{H} / \mathrm{H})$

$\mathrm{H} / \mathrm{H}=(\mathrm{c} 9 \mathrm{C} 18: 1 \mathrm{OL}+\mathrm{C} 18: 2 \mathrm{LA}+\mathrm{C} 18: 3$ ALA $) /(\mathrm{C} 14: 0+\mathrm{C} 16: 0)$

\subsubsection{Cholesterol content determination}

Cholesterol was determined using the RP-HPLC method with UV detection at 210 $\mathrm{nm}$. To about $50 \mathrm{mg}$ of egg yolk $2 \mathrm{~mL} 0.5 \mathrm{M} \mathrm{KOH}$ in ethanol and $20 \mu \mathrm{L}$ of butylated hydroxytoluene solution ( $5 \mathrm{mg} \mathrm{mL}^{-1}$ in ethanol) were added. The sample was put into an ultrasonic bath for 20 minutes and heated at $80^{\circ} \mathrm{C}$ for 30 minutes. Then $4 \mathrm{~mL}$ of the citric acid solution $(4.5 \% \mathrm{w} / \mathrm{v}$ in water) and $4 \mathrm{~mL}$ of hexane were added and shaken for 5 minutes. After phase separation, the upper layer was transferred into a $10 \mathrm{ml}$ volumetric flask. Extraction was repeated twice with $2 \mathrm{~mL}$ hexane. Volumetric flask was filled to the mark by hexane and mixed thoroughly. $500 \mu \mathrm{L}$ of the solution was transferred to a $2 \mathrm{ml}$ vial and evaporated under a stream of nitrogen. Dry residue was dissolved in $500 \mu \mathrm{L}$ of isopropanol.

Chromatographic analysis was performed on a Merck Hitachi HPLC system (Darmstadt, Germany; pump: L-7100; UV-VIS detector: L-7420). Separation was carried 
out on Luna 5uC18(2) (Phenomenex, Torrance, CA, USA; pore size: 100 Ĺ, L × I.D.: $150 \times 2$ $\mathrm{mm}$ ) operated at $35^{\circ} \mathrm{C}$. Isocratic elution was executed with mixture of acetonitrile and isopropanol $(9: 1, \mathrm{v} / \mathrm{v})$. Flow rate was $0.4 \mathrm{~mL} \mathrm{~min}^{-1}$ and injection volume $10 \mu \mathrm{L}$ were used. The cholesterol concentration was calculated against the calibration curve.

\subsubsection{Iron and Zinc content determination}

Iron and Zinc determination was carried out by atomic absorption spectrometry. Before the analysis, the egg yolk samples were mineralised by microwave mineralizer (Plazmatronika, Ertec, Wroclaw, Poland) in a nitric acid medium. 0.3-0.4 g of sample was weighed directly into a closed PTFE vessel and $6 \mathrm{~mL}$ of nitric acid (ultrapure) was added. The heating program was performed in three steps: [a] $4 \mathrm{~min}$, power: $80 \%$, pressure: 19-22 atm; [b] $4 \mathrm{~min}$, power: $90 \%$, pressure: $23-26 \mathrm{~atm}$; [c] $8 \mathrm{~min}$, power: $100 \%$, pressure 33-36 atm. Mineralizate was diluted with ultra-pure water to $10 \mathrm{ml}$.

The determination was carried out by an air-acetylene flame atomic absorption spectrometer (Philips Analytical PU-9100, Cambridge, GB) with a single element hollow cathode lamp. The analytical wavelength was $248.3 \mathrm{~nm}$ for Fe and $213.9 \mathrm{~nm}$ for $\mathrm{Zn}$, respectively. Minerals concentration was calculated against the calibration curve.

\subsection{Statistical analysis}

All chemical analyses were performed in triplicate. Results are presented as mean values $(x) \pm$ standard deviation (SD). Distributions of the data (normality) was assessed by Shapiro-Wilk test. Differences among examined groups of eggs were analysed with one-way ANOVA $(\alpha=0.05)$, with post-hoc RIR Tukey test $(\alpha=0.05)$. Cluster analysis of lipids components content (fatty acids, cholesterol) in eggs yolk was performed; Ward agglomeration procedure and Euclidean function of the distance was applied. Cut-off point was established at 33\% of the maximum distance, according to the Sneath's criterion.

All results were evaluated using Statistica 13.3 software (StatSoft, Kraków, Poland.

\section{Results}

In the present study, the content of lipid components (fatty acids, cholesterol), iron and zinc in selected groups of eggs available on the market was assessed. Hen egg weight, shell weight, yolk weight, and the share of edible parts between products from hens did not differ significantly. Quail eggs were clearly smaller, therefore the other factors mentioned above were also much lower. Fat content in eggs yolk differed between egg groups, the largest was in products from ecological production $(32.0 \%)$, the lowest in egg yolks from caged hens (25.7\%). Characteristic of examined eggs samples is presented in Table 1.

The examined groups of eggs differed in the content and profile of fatty acids. The results of fatty acids and cholesterol content in egg yolks (in mg g- 1 of yolk) are presented in Table 2, while the share of the main groups of fatty acids in the total FA content and FA quality indices are in Table 3. 
Table 1. Characteristic of examined egg samples $(\mathrm{x} \pm \mathrm{SD})$

\begin{tabular}{|c|c|c|c|c|c|c|c|c|}
\hline Group & $\mathrm{E}$ & $\mathbf{F}$ & B & $\mathrm{C}$ & N3 & GL & $Q$ & $P$ value \\
\hline Egg [g] & $60.0 \pm 4.7 \mathrm{~b}$ & $62.9 \pm 2.0 \mathrm{a}, \mathrm{b}$ & $62.0 \pm 4.8 \mathrm{a}, \mathrm{b}$ & $61.3 \pm 3.6 \mathrm{a}, \mathrm{b}$ & $64.2 \pm 3.9 \mathrm{a}$ & $56.4 \pm 4.5$ & $11.9 \pm 1.0$ & $<0.001$ \\
\hline Yolk [g] & $17.0 \pm 1.8$ a & $17.1 \pm 1.1^{a}$ & $17.0 \pm 1.7$ a & $17.1 \pm 1.3 \mathrm{a}$ & $17.4 \pm 1.7$ a & $16.9 \pm 2.0^{a}$ & $4.60 \pm 0.69$ & $<0.001$ \\
\hline Eggshell [g] & $7.46 \pm 0.566^{b, c}$ & $7.95 \pm 0.50 \mathrm{a}, \mathrm{b}$ & $8.24 \pm 1.14 \mathrm{a}, \mathrm{b}$ & $8.02 \pm 0.93 a, b$ & $8.37 \pm 0.87$ a & $7.12 \pm 0.63 c$ & $1.66 \pm 0.18$ & $<0.001$ \\
\hline Edible part [g] & $52.5 \pm 4.3 \mathrm{a}$ & $55.0 \pm 1.9$ a & $53.7 \pm 4.4$ a & $53.3 \pm 3.2 \mathrm{a}$ & $55.8 \pm 3.4$ a & $49.3 \pm 4.1$ & $10.2 \pm 0.9$ & $<0.001$ \\
\hline Yolk fat [\%] & $32.0 \pm 7.1^{\mathrm{a}}$ & $29.5 \pm 2.5^{\mathrm{a}, \mathrm{b}}$ & $29.6 \pm 4.8^{\mathrm{a}, \mathrm{b}}$ & $25.7 \pm 5.0^{b}$ & $28.7 \pm 7.2^{\mathrm{a}, \mathrm{b}}$ & $26.9 \pm 4.2 \mathrm{~b}$ & $30.0 \pm 5.1^{a, b}$ & 0.002 \\
\hline
\end{tabular}

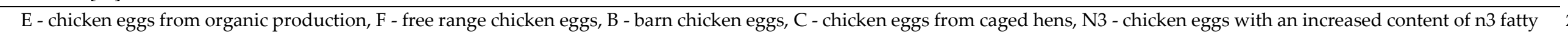
acids, GL - chicken eggs from Green-legged Partridge, Q - partridge quail eggs

$P$ value, result of one-way ANOVA $(\alpha=0.05)$

a-c homogeneous groups in rows; comparison between product groups (Tukey's test, $\alpha=0.05$ ) 
Table 2. Fatty acids and cholesterol content in examined eggs yolk $(\mathrm{x} \pm \mathrm{SD})$.

\begin{tabular}{|c|c|c|c|c|c|c|c|c|}
\hline Group & $\mathrm{E}$ & $\mathbf{F}$ & B & $\mathrm{C}$ & N3 & GL & $Q$ & P value \\
\hline Fatty acids & {$\left[\mathrm{mg} \mathrm{g}^{-1}\right]$} & & & & & & & \\
\hline C14:0 & $0.96 \pm 0.26^{a}$ & $0.86 \pm 0.15 a, b$ & $0.92 \pm 0.19 \mathrm{a}, \mathrm{b}$ & $0.74 \pm 0.20^{b}$ & $0.81 \pm 0.22 \mathrm{a}, \mathrm{b}$ & $0.82 \pm 0.23 \mathrm{a}, \mathrm{b}$ & $1.25 \pm 0.26$ & $<0.001$ \\
\hline C15:0 & $0.26 \pm 0.14 \mathrm{a}, \mathrm{b}$ & $0.22 \pm 0.05 \mathrm{a}, \mathrm{b}$ & $0.28 \pm 0.14 \mathrm{a}, \mathrm{b}$ & $0.19 \pm 0.07 \mathrm{~b}$ & $0.39 \pm 0.44$ a & $0.24 \pm 0.13 \mathrm{a}, \mathrm{b}$ & $0.18 \pm 0.05 \mathrm{~b}$ & 0.011 \\
\hline C16:0 & $65.3 \pm 15.7 \mathrm{a}$ & $61.2 \pm 5.8 \mathrm{a}, \mathrm{b}$ & $64.2 \pm 10.5$ a & $52.7 \pm 11.4^{b}$ & $58.2 \pm 15.8 \mathrm{a}, \mathrm{b}$ & $56.0 \pm 10.0 \mathrm{a}, \mathrm{b}$ & $64.6 \pm 12.1$ & 0.002 \\
\hline C17:0 & $0.59 \pm 0.17 \mathrm{a}$ & $0.53 \pm 0.08^{a, b}$ & $0.51 \pm 0.18^{a, b}$ & $0.47 \pm 0.16^{b}$ & $0.52 \pm 0.18 \mathrm{a}, \mathrm{b}$ & $0.49 \pm 0.11^{a, b}$ & $0.44 \pm 0.05^{b}$ & 0.031 \\
\hline C18:0 & $20.9 \pm 4.8^{\mathrm{a}, \mathrm{b}}$ & $19.2 \pm 2.4 \mathrm{~b}, \mathrm{c}$ & $18.7 \pm 3.4^{b, c}$ & $15.5 \pm 2.6^{d}$ & $17.0 \pm 4.4 \mathrm{c,d}$ & $17.7 \pm 3.0 \mathrm{c}, \mathrm{d}$ & $22.8 \pm 3.8^{a}$ & $<0.001$ \\
\hline C20:0 & $0.13 \pm 0.04^{a}$ & $0.12 \pm 0.03 a, b$ & $0.14 \pm 0.03{ }^{a}$ & $0.10 \pm 0.04^{b}$ & $0.13 \pm 0.05 \mathrm{a}, \mathrm{b}$ & $0.12 \pm 0.03 a, b$ & $0.14 \pm 0.04^{\mathrm{a}}$ & 0.002 \\
\hline C21:0 & $0.36 \pm 0.13 a$ & $0.36 \pm 0.10 \mathrm{a}$ & $0.31 \pm 0.11$ & $0.32 \pm 0.12 \mathrm{a}$ & $0.32 \pm 0.18$ & $0.34 \pm 0.14 \mathrm{a}$ & $0.17 \pm 0.05$ & $<0.001$ \\
\hline C24:0 & $0.56 \pm 0.22 \mathrm{~b}, \mathrm{c}$ & $0.90 \pm 0.44$ & $0.79 \pm 0.37 \mathrm{a}, \mathrm{b}$ & $0.72 \pm 0.38 \mathrm{a}, \mathrm{b}$ & $0.67 \pm 0.58 \mathrm{a}, \mathrm{b}$ & $0.52 \pm 0.24^{b, c}$ & $0.43 \pm 0.20^{c}$ & $<0.001$ \\
\hline SFA & $89.1 \pm 20.6 \mathrm{a}$ & $83.4 \pm 8.0 \mathrm{a}, \mathrm{b}$ & $85.9 \pm 14.2 \mathrm{a}$ & $70.9 \pm 14.0 \mathrm{~b}$ & $78.1 \pm 21.5^{\mathrm{a}, \mathrm{b}}$ & $76.2 \pm 13.2 \mathrm{a}, \mathrm{b}$ & $90.1 \pm 15.9$ a & $<0.001$ \\
\hline C14:1 & $0.20 \pm 0.11 \mathrm{a}, \mathrm{b}$ & $0.17 \pm 0.06 \mathrm{a}, \mathrm{b}$ & $0.23 \pm 0.08{ }^{a}$ & $0.14 \pm 0.05^{b}$ & $0.17 \pm 0.09 \mathrm{a}, \mathrm{b}$ & $0.19 \pm 0.13 \mathrm{a}, \mathrm{b}$ & $0.22 \pm 0.05 a, b$ & 0.008 \\
\hline C16:1 & $8.65 \pm 3.71^{a-c}$ & $7.64 \pm 1.93 \mathrm{c}$ & $10.04 \pm 2.23 \mathrm{a}, \mathrm{b}$ & $6.62 \pm 2.09 c$ & $8.28 \pm 2.89 a-c$ & $7.90 \pm 2.77 b, c$ & $10.59 \pm 2.96 \mathrm{a}$ & $<0.001$ \\
\hline C17:1 & $0.42 \pm 0.11 \mathrm{a}$ & $0.33 \pm 0.06 \mathrm{~b}, \mathrm{c}$ & $0.39 \pm 0.12 \mathrm{a}, \mathrm{b}$ & $0.31 \pm 0.09 \mathrm{c}$ & $0.40 \pm 0.13 \mathrm{a}, \mathrm{b}$ & $0.35 \pm 0.05^{a-c}$ & $0.28 \pm 0.06^{c}$ & $<0.001$ \\
\hline c9 C18:1 OL & $106.3 \pm 24.0 \mathrm{a}$ & $96.3 \pm 10.6 \mathrm{a}, \mathrm{b}$ & $95.4 \pm 15.7 \mathrm{a}, \mathrm{b}$ & $85.0 \pm 16.3^{b}$ & $96.3 \pm 22.2 \mathrm{a}, \mathrm{b}$ & $89.5 \pm 11.5^{b}$ & $96.1 \pm 20.6 \mathrm{a}$ ab & 0.004 \\
\hline c11 C18:1 & $8.95 \pm 3.30 \mathrm{a}$ & $7.32 \pm 1.30 \mathrm{a}-\mathrm{c}$ & $8.25 \pm 1.94 \mathrm{a}, \mathrm{b}$ & $6.57 \pm 1.26^{b, c}$ & $7.55 \pm 2.03 \mathrm{a}, \mathrm{b}$ & $7.45 \pm 1.77 \mathrm{a}, \mathrm{b}$ & $5.35 \pm 1.09 c$ & $<0.001$ \\
\hline C20:1 & $0.48 \pm 0.15^{a}$ & $0.41 \pm 0.06^{a}$ & $0.41 \pm 0.11^{a}$ & $0.39 \pm 0.10^{a}$ & $0.50 \pm 0.20 \mathrm{a}$ & $0.46 \pm 0.12^{a}$ & $0.25 \pm 0.09$ & $<0.001$ \\
\hline MUFA & $124.2 \pm 30.0^{a}$ & $110.1 \pm 13.4^{\mathrm{a}, \mathrm{b}}$ & $113.7 \pm 18.1$ & $97.4 \pm 19.2^{b}$ & $112.8 \pm 25.8 \mathrm{a}, \mathrm{b}$ & $104.7 \pm 15.1 \mathrm{~b}$ & $112.5 \pm 24.5 \mathrm{a}, \mathrm{b}$ & 0.002 \\
\hline C18:2 LA & $42.5 \pm 12.5$ & $42.8 \pm 9.2$ & $36.7 \pm 10.4$ & $37.6 \pm 10.4$ & $38.5 \pm 14.2$ & $34.6 \pm 9.0$ & $35.9 \pm 4.6$ & 0.050 \\
\hline C18:3 GLA & $0.28 \pm 0.09 a$ & $0.27 \pm 0.07 \mathrm{a}$ & $0.29 \pm 0.10^{a}$ & $0.22 \pm 0.08{ }^{a}$ & $0.26 \pm 0.10^{a}$ & $0.25 \pm 0.08{ }^{a}$ & $0.53 \pm 0.16$ & $<0.001$ \\
\hline C18:3 ALA & $2.12 \pm 0.61 \mathrm{a}$ & $1.38 \pm 0.81^{b}$ & $2.00 \pm 1.71^{\mathrm{a}, \mathrm{b}}$ & $1.34 \pm 0.86^{b}$ & $1.85 \pm 0.93 \mathrm{a}, \mathrm{b}$ & $1.55 \pm 0.49 \mathrm{a}, \mathrm{b}$ & $1.78 \pm 1.08 \mathrm{a}, \mathrm{b}$ & 0.047 \\
\hline C20:2 & $0.09 \pm 0.05 \mathrm{a}$ & $0.07 \pm 0.02 \mathrm{a}$ & $0.09 \pm 0.03 \mathrm{a}$ & $0.06 \pm 0.03$ & $0.08 \pm 0.05^{a}$ & $0.09 \pm 0.04^{a}$ & $0.15 \pm 0.07$ & $<0.001$ \\
\hline C20:3 & $0.32 \pm 0.08$ & $0.27 \pm 0.05$ & $0.29 \pm 0.07$ & $0.26 \pm 0.09$ & $0.27 \pm 0.1$ & $0.30 \pm 0.07$ & $0.29 \pm 0.09$ & 0.180 \\
\hline C20:4 AA & $4.54 \pm 1.16 \mathrm{a}, \mathrm{b}$ & $4.54 \pm 0.81 \mathrm{a}, \mathrm{b}$ & $4.12 \pm 0.96 \mathrm{a}-\mathrm{c}$ & $3.68 \pm 0.91^{c}$ & $3.78 \pm 1.12 b, c$ & $3.93 \pm 0.67 b, c$ & $5.01 \pm 1.16 \mathrm{a}$ & $<0.001$ \\
\hline C20:5 EPA & $0.06 \pm 0.06 \mathrm{a}, \mathrm{b}$ & $0.03 \pm 0.01 b$ & $0.09 \pm 0.07 \mathrm{a}, \mathrm{b}$ & $0.03 \pm 0.01^{b}$ & $0.06 \pm 0.05 \mathrm{a}, \mathrm{b}$ & $0.03 \pm 0.02 \mathrm{~b}$ & $0.11 \pm 0.07 \mathrm{a}$ & 0.001 \\
\hline C22:2 & $0.13 \pm 0.09$ & $0.14 \pm 0.08$ & $0.14 \pm 0.13$ & $0.17 \pm 0.13$ & $0.12 \pm 0.08$ & $0.18 \pm 0.26$ & $0.11 \pm 0.05$ & 0.622 \\
\hline C22:5 & $0.29 \pm 0.10 \mathrm{a}, \mathrm{b}$ & $0.18 \pm 0.08^{c}$ & $0.24 \pm 0.13^{b, c}$ & $0.17 \pm 0.10^{c}$ & $0.21 \pm 0.11 b, c$ & $0.19 \pm 0.10^{c}$ & $0.36 \pm 0.06 \mathrm{a}$ & $<0.001$ \\
\hline C22:6 DHA & $2.12 \pm 0.46^{a}$ & $1.37 \pm 0.61^{b}$ & $1.81 \pm 0.74 \mathrm{a}, \mathrm{b}$ & $1.45 \pm 0.81^{b}$ & $1.96 \pm 1.10 \mathrm{a}, \mathrm{b}$ & $1.49 \pm 0.27 \mathrm{~b}$ & $1.97 \pm 0.29 a \mathrm{a}, \mathrm{b}$ & $<0.001$ \\
\hline PUFA & $52.4 \pm 14.0$ & $51.1 \pm 9.2$ & $45.8 \pm 12.5$ & $44.9 \pm 12.2$ & $47.0 \pm 15.7$ & $42.6 \pm 10.3$ & $46.2 \pm 5.2$ & 0.062 \\
\hline
\end{tabular}




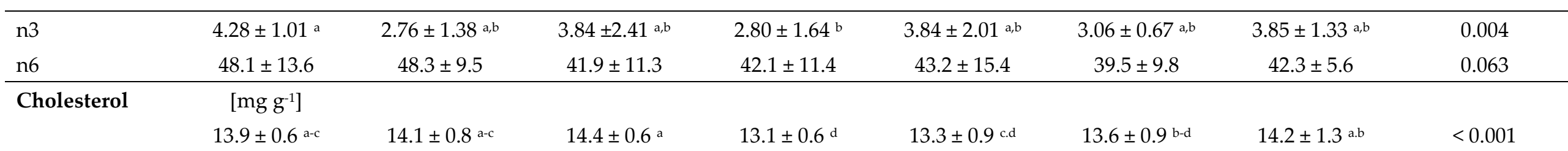

E - chicken eggs from organic production, F - free range chicken eggs, B - barn chicken eggs, C - chicken eggs from caged hens, N3 - chicken eggs with an increased 7 content of n3 fatty acids, GL - chicken eggs from Green-legged Partridge, $\mathrm{Q}$ - partridge quail eggs

$P$ value, result of one-way ANOVA $(\alpha=0.05)$

a-d homogeneous groups in rows; comparison between product groups (Tukey's test, $\alpha=0.05$ ) 
Table 3. The share of the main groups of fatty acids in the total FA content and fat quality indices $(x \pm S D)$ in eggs yolk.

\begin{tabular}{|c|c|c|c|c|c|c|c|c|}
\hline Group & $\mathbf{E}$ & $\mathbf{F}$ & B & $\mathrm{C}$ & N3 & GL & $\mathbf{Q}$ & $P$ value \\
\hline SFA [\%] & $33.5 \pm 1.18^{c}$ & $34.1 \pm 1.0 \mathrm{~b}, \mathrm{c}$ & $35.0 \pm 0.89 a \mathrm{a}, \mathrm{b}$ & $33.3 \pm 1.2 \mathrm{c}$ & $32.8 \pm 2.2 \mathrm{c}$ & $34.1 \pm 1.5 \mathrm{~b}, \mathrm{c}$ & $36.2 \pm 1.5 \mathrm{a}$ & $<0.001$ \\
\hline MUFA [\%] & $46.7 \pm 3.8$ & $45.0 \pm 3.8$ & $46.4 \pm 3.3$ & $45.7 \pm 3.8$ & $47.6 \pm 3.2$ & $47.0 \pm 2.4$ & $44.9 \pm 3.2$ & 0.100 * \\
\hline PUFA [\%] & $19.8 \pm 3.9$ & $20.9 \pm 3.7$ & $18.6 \pm 3.48$ & $21.0 \pm 3.40$ & $19.6 \pm 3.13$ & $19.9 \pm 2.8$ & $18.9 \pm 2.7$ & 0.086 * \\
\hline n3 PUFA [\%] & $1.64 \pm 0.37 \mathrm{a}$ & $1.13 \pm 0.56 b$ & $1.57 \pm 1.02 \mathrm{a}$ & $1.26 \pm 0.56^{b}$ & $1.65 \pm 0.844^{a}$ & $1.37 \pm 0.23 a$ & $1.66 \pm 0.90 \mathrm{a}$ & 0.042 \\
\hline n6 PUFA [\%] & $18.2 \pm 3,8^{a, b}$ & $19.8 \pm 3.9$ a & $17.0 \pm 2.9 \mathrm{~b}$ & $19.7 \pm 3,6^{a}$ & $17.9 \pm 2.9 \mathrm{a}, \mathrm{b}$ & $17.6 \pm 2.7 \mathrm{a}, \mathrm{b}$ & $17.2 \pm 2.1^{\mathrm{a}, \mathrm{b}}$ & 0.015 \\
\hline n6/n3 PUFA & $10.7 \pm 3.0^{c}$ & $24.2 \pm 18.5^{a}$ & $12.5 \pm 4.7 \mathrm{~b}, \mathrm{c}$ & $20.3 \pm 14.6 \mathrm{a}, \mathrm{b}$ & $13.4 \pm 8.1 \mathrm{~b}, \mathrm{c}$ & $12.1 \pm 1.8^{b, c}$ & $10.6 \pm 2.8^{c}$ & $<0.001$ \\
\hline FLQ & $0.83 \pm 0.17 \mathrm{a}$ & $0.57 \pm 0.25 \mathrm{~b}$ & $0.75 \pm 0.30 \mathrm{a}, \mathrm{b}$ & $0.66 \pm 029 \mathrm{a}, \mathrm{b}$ & $0.86 \pm 0.47 \mathrm{a}$ & $0.69 \pm 0.14 \mathrm{a}, \mathrm{b}$ & $0.86 \pm 0.26$ & 0.003 \\
\hline AI & $0.39 \pm 0.02 \mathrm{~b}$ & $0.40 \pm 0.02 b$ & $0.43 \pm 0.02 \mathrm{a}$ & $0.39 \pm 0.03 \mathrm{~b}$ & $0.39 \pm 0.04 b$ & $0.40 \pm 0.03^{b}$ & $0.44 \pm 0.03{ }^{a}$ & $<0.001$ \\
\hline $\mathrm{TI}$ & $0.88 \pm 0.06 \mathrm{c,d}$ & $0.93 \pm 0.05^{a-c}$ & $0.94 \pm 0.07 \mathrm{a}, \mathrm{b}$ & $0.89 \pm 0.07 b-d$ & $0.85 \pm 0.12 \mathrm{~d}$ & $0.91 \pm 0.07 \mathrm{~b}-\mathrm{d}$ & $0.99 \pm 0,09 a$ & $<0.001$ \\
\hline OFA & $24.9 \pm 1.1^{c}$ & $25.4 \pm 1.0 \mathrm{~b}, \mathrm{c}$ & $26.6 \pm 1.0 \mathrm{a}$ & $25.0 \pm 1.2^{c}$ & $24.8 \pm 1.7 \mathrm{c}$ & $25.7 \pm 1.5^{b, c}$ & $26.4 \pm 0.9 \mathrm{a}, \mathrm{b}$ & $<0.001$ \\
\hline DFA & $74.6 \pm 1.1^{a}$ & $73.7 \pm 0.9 \mathrm{a}, \mathrm{b}$ & $72.6 \pm 1.0^{c}$ & $74.1 \pm 1.3 \mathrm{a}, \mathrm{b}$ & $74.4 \pm 1.8 \mathrm{a}$ & $73.9 \pm 1.5 \mathrm{a}, \mathrm{b}$ & $73.0 \pm 1.5^{b, c}$ & $<0.001$ \\
\hline $\mathrm{H} / \mathrm{H}$ & $2.29 \pm 0.19 \mathrm{a}$ & $2.27 \pm 0.17 \mathrm{a}$ & $2.06 \pm 0.14^{c}$ & $2.33 \pm 0.17 \mathrm{a}$ & $2.33 \pm 0.27 \mathrm{a}$ & $2.23 \pm 0.19 a, b$ & $2.04 \pm 0.14^{b, c}$ & $<0.001$ \\
\hline \multicolumn{9}{|c|}{$\begin{array}{l}\text { FLQ - flesh-lipid quality; AI - index of atherogenicity; TI- index of thrombogenicity; OFA - hypercholesterolaemic fatty acids; DFA- hypocholesterolaemic fatty acids; H/H - hypo- } \\
\text { cholesterolemic to hypercholesterolemic ratio }\end{array}$} \\
\hline \multicolumn{9}{|c|}{$\begin{array}{l}\text { E - chicken eggs from organic production, F - free range chicken eggs, B - barn chicken eggs, C - chicken eggs from caged hens, N3 - chicken eggs with an increased content of n3 fatty } \\
\text { acids, GL - chicken eggs from Green-legged Partridge, Q - partridge quail eggs } \\
\text { P value, result of one-way ANOVA ( } \alpha=0.05) ;{ }^{*} \text { lack of differences between product groups }\end{array}$} \\
\hline
\end{tabular}


The content of saturated fatty acids (SFA) ranged from $32.8 \%(\mathrm{~N} 3)$ to $36.2 \%(\mathrm{Q})$ of total fatty acids (TFA). The dominant saturated fatty acid was palmitic acid; its average content was $25.1 \%$ TFA. The lowest C16:0 levels were found in egg yolks from caged hens (24.2\% TFA), and the highest in barn (25.8\% TFA) and quail eggs (25.5\% TFA). The second SFA in egg yolks was stearic acid (C18:0). The highest levels were determined in quail eggs (9.1\% TFA). The mean content of this acid in chicken eggs was $7.6 \%$ TFA. The content of remaining SFA (C13:0, C14:0, C15:0, C17:0, C20:0, C21:0, C24:0) determined in eggs did not exceed $0.5 \%$ of TFA.

Monounsaturated fatty acids (MUFA) dominated in egg yolks, which constituted on average $45.7 \%$ of the TFA. Oleic acid (c9 C18:1, OL) was the main one. Although its content significantly differed between the examined eggs, the share in the total pool of fatty acids (average 39.7\% TFA) was similar $(\mathrm{p}=0.189)$. The content of palmitoleic acid $(\mathrm{C} 16: 1)$ ranged from $3.04(\mathrm{C})$ to $4.13(\mathrm{Q}) \%$ TFA, while the $\mathrm{c} 11 \mathrm{C} 18: 1$ acid ranged from $2.08(\mathrm{Q})$ to 3.27 (GL)\% TFA. The content of the remaining MUFA (C14:1, C15:1, C17:1, C20:1) did not exceed $0.2 \%$ TFA.

The content of polyunsaturated fatty acids (PUFA) was average 19.7\% TFA and did not differ significantly between the examined groups. Linoleic acid (c9c12 C18:2, LA) was the dominant PUFA. Its share [\%] in TFA ranged from 14.4 (Q) to 17.4 (C). The second largest n6 PUFA fatty acid was arachidonic acid (c5c8c11c14C20:4, AA); its amount was between $1.58(\mathrm{~N} 3)$ and $1.96(\mathrm{Q}) \%$ TFA. The content of $\alpha$-linolenic acid (c9c12c15 C18:3, ALA), belonging to the $\mathrm{n} 3$ family, did not differ significantly between the groups; the average level was $0.72 \%$. The content of long-chain PUFA from the $\mathrm{n} 3$ fatty acid family was low. The share of eicosapentaenoic acid (c5c8c11c14c17 C20:5, EPA) in any group did not exceed $0.05 \%$ TFA. The docosahexaenoic acid (c4c7c10c13c16c19 C22:6, DHA) level was higher, ranging between $0.56(\mathrm{~F})$ and $0.8(\mathrm{E}, \mathrm{Q}) \%$ of TFA. The FLQ index, being the sum of the share of EPA and DHA in TFA, differed significantly between the studied groups of products. The highest value was recorded for N3 and quail eggs (0.86) and the lowest for free range chicken eggs (0.57). The content of the remaining determined PUFAs (C18:3 n6, C20:2, C20:3, C22:2) was low, not exceeding 0.2\% of TFA. The n6 to n3 polyunsaturated fatty acids ratio fluctuated within a wide range between the studied groups. Egg yolks from free-range chicken had the highest value (24.2), while egg yolks from ecological production and quail eggs had the lowest (10.6).

Index of atherogenicity (AI) was calculated between 0.39 (E, C, N3) and 0.44 for quail egg fat. Index of thrombogenicity (TI) was the lowest for N3 eggs fat (0.85) and the highest for quail egg fat (0.99). The richest in hypercholesterolaemic fatty acids (OFA) was barn chicken eggs. OFA was lowest in N3 eggs fat. Hypocholesterolaemic fatty acids (DFA) levels are inversely proportional to OFA $(\mathrm{r}=0.989)$. DFA was highest for fat from N3 eggs (74.36) and the lowest for fat from barn chicken eggs (72.6). Hypocholesterolemic to hypercholesterolemic ratio was ranged in $2.04(\mathrm{Q})$ and $2.33(\mathrm{C}, \mathrm{N} 3)$.

Cholesterol levels ranged from $13.09 \mathrm{mg} \mathrm{g}^{-1}$ to $14.35 \mathrm{mg} \mathrm{g}^{-1}$. The highest content of this compound was found in barn chicken eggs yolks and the lowest in eggs yolks from caged hens. The cholesterol amount in one hen egg was on average 234.4 and $65.2 \mathrm{mg}$ in quail eggs, but in $100 \mathrm{~g}$ of eggs levels were 385.4 and $545.7 \mathrm{mg}$, respectively. In $100 \mathrm{~g}$ of edible parts of a chicken eggs $442.3 \mathrm{mg}$ and $634.2 \mathrm{mg}$ in quail eggs.

In cluster analysis of lipids components, three clusters were distinguished. The first cluster includes most of the examined chicken eggs (E, GL, B, F, C), except for N3. In the second cluster are N3 eggs, in the third one quail eggs. Content of lipid compounds in quail eggs significantly differed from their content in chickens eggs. Results are presented in Figure 1. 


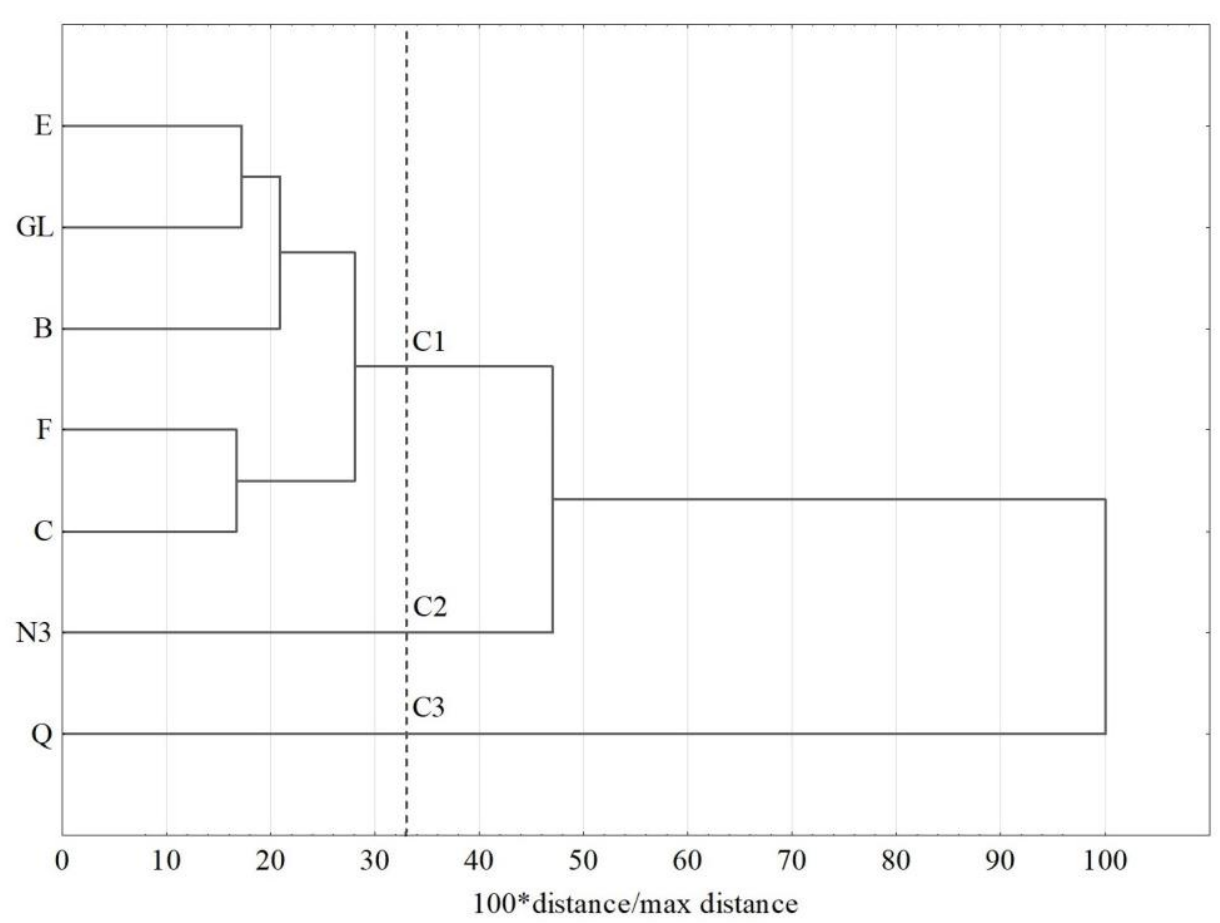

Figure 1. Dendrogram of similarity in fatty acid and cholesterol content in yolk fat of investigated groups of eggs; C1-C3 - clusters.

E - chicken eggs from organic production, F - free range chicken eggs, B - barn chicken eggs, C chicken eggs from caged hens, N3 - chicken eggs with an increased content of n3 fatty acids, GL chicken eggs from Green-legged Partridge, Q - partridge quail eggs

The iron content in egg yolks differed between the studied groups. The lowest amount was found in GL eggs $\left(40.7 \mu \mathrm{g} \mathrm{g}^{-1}\right)$, and the highest in the yolk of quail eggs (57.2 $\left.\mu \mathrm{g} \mathrm{g}^{-1}\right)$. The amount of Fe in $100 \mathrm{~g}$ of chicken eggs was on average $1.26 \mathrm{mg}$ and $2.20 \mathrm{mg}$ in $100 \mathrm{~g}$ of quail eggs. For $100 \mathrm{~g}$ of edible parts, the results were 1.45 and 2.56, respectively. Zinc levels in egg yolks did not differ significantly between groups, the mean content of this mineral was $29.1 \mathrm{\mu g} \mathrm{g}^{-1}$. The results of the iron and zinc content in the examined product groups are presented in Table 4. 
Table 4. Iron and zinc content in eggs yolk $(x \pm S D)$.

\begin{tabular}{|c|c|c|c|c|c|c|c|c|}
\hline Group & E & $\mathbf{F}$ & B & C & N3 & GL & $\mathbf{Q}$ & $P$ value \\
\hline Iron $\left[\mu \mathrm{g} \mathrm{g}^{-1}\right]$ & $43.5 \pm 7.0 \mathrm{a}, \mathrm{b}$ & $49.1 \pm 8.8^{a}$ & $49.3 \pm 6.6^{a}$ & $44.1 \pm 6.8 \mathrm{a}, \mathrm{b}$ & $47.7 \pm 5.9 \mathrm{a}, \mathrm{b}$ & $40.7 \pm 8.0^{b}$ & $57.2 \pm 6.8$ & $<0.001$ \\
\hline $\operatorname{Zinc}\left[\mu \mathrm{g} \mathrm{g}^{-1}\right]$ & $28.6 \pm 3.3$ & $29.3 \pm 3.1$ & $28.2 \pm 2.0$ & $28.5 \pm 3.2$ & $29.8 \pm 2.4$ & $29.4 \pm 3.1$ & $30.5 \pm 4.0$ & 0.216 \\
\hline
\end{tabular}

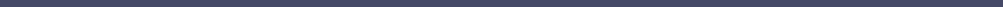




\section{Discussion}

Dietary fatty acids affect the level of low- and high- density lipoproteins and thus the dynamic of atherosclerotic plaque formation. They may be pro- or anti- atherogenic and thrombogenic [15]. However, dietary fatty acids affect not only the proper function of the circulatory system in the body but also the immune, neurological and many others $[16,17]$. Eggs are an important part of the diet of a large part of the population therefore their fatty acid composition can affect the daily lipid profile of the diet. In $100 \mathrm{~g}$ of the edible part of chicken eggs, there is an average of $9.2 \mathrm{~g}$ (13.4 $\mathrm{g}$ in quail eggs) of fat. The average content of fatty acids in eggs fat is $83 \%$ [18], which gives $7.7 \mathrm{~g}$ of fatty acids (11.1 $\mathrm{g}$ for quail) in $100 \mathrm{~g}$ of edible parts of these products.

There are twice as many unsaturated fatty acids as the saturated ones in eggs. The dominant FA is oleic acid, which has a beneficial effect on the prevention of CVD [19]. Linoleic acid is also of considerable value as one of the essential unsaturated fatty acids [20]. Unfortunately, the ratio of n6/n3 PUFAs is not the best, so the efforts of producers to increase the content of n3 PUFA seem to be reasonable. The recommended daily intake (RDI) of EPA and DHA with the diet by various organizations (including WHO and EFSA) is between 200 and over $600 \mathrm{mg}$ per day, most often around $250 \mathrm{mg}$ [21]. Considering the content of these acids in eggs, consumption of $100 \mathrm{~g}$ of edible parts (about two chicken eggs) covers over $20 \%$ of RDI, while quail eggs - about $37 \%$.

The beneficial composition of fatty acids is best illustrated by the lipid quality indices. These indices were created to approximate the effect of fat on the body [13]. The index of atherogenicity was first described by Ulbricht and Southgate in 1991 [22]. It characterizes the atherogenic potential of FA. The higher values are associated with a greater atherogenic effect on the body. In eggs, this AI was about 0.4. In other animal products, it is usually higher. For example, for fish, it ranges from $0.2-1.2$ [23-26], red meat $0.3-1.3$ [27-30], milk and its products 1.0 - 5.0 [31-35]. Naturally, vegetable oils have an incomparably lower AI [36].

The same authors who developed AI also proposed an index of thrombogenicity [22], referring to the ability to form clots. Like AI, the higher the TI value is, the stronger the thrombogenic effect on the body is exerted. The lowest TI among animal products, due to the high share of N3 PUFA, were found in fishes $(0.1-0.8)[14,23,26,37]$. In the examined eggs, the TI was 0.8-1.0, whereas in red meat it ranges from 0.8-1.6 [28,38,39], and in milk and its products from 0.4 (yoghurt) to 5.0 [33-35].

The indices of hypercholesterolemic fatty acids (OFA) and hypocholesterolemic fatty acids (DFA) indicate the potential influence on the increase or reduction of the total and LDL cholesterol levels in the blood serum. In 2002 Santos-Silva et al. [40] proposed a hypocholesterolemic to hypercholesterolemic ratio. The higher the $\mathrm{H} / \mathrm{H}$ index, the more beneficial the effect of fat on the body. The $\mathrm{H} / \mathrm{H}$ ratio for eggs was determined at the level of 2.0 - 2.3. For fish it was $0.9-2.9$ [24], for red meat 1.2-2.6 [40-42], and for dairy products $0.3-1.3[33,34,43] . \mathrm{H} / \mathrm{H}$ index for vegetable oils is usually 5.0-15.0 [44,45]. The values of the indices, just like the fatty acid profile (based on which they are calculated), depend on many factors. Nevertheless, egg lipids compared to other products of animal origin (except for fish oil) are characterized by favourable values of these indicators.

Eggs are a source of high amounts of cholesterol [46]. While there is currently no evidence that dietary cholesterol adversely affects the level of LDL in the body, it is a compound that can be oxidized. Oxidized cholesterol derivatives (COPs) are much better absorbed from the gastrointestinal tract than cholesterol itself [47]. The high levels of these compounds in the body are very unfavourable. COPs act in many directions and may contribute to the development of non-communicable diseases [48]. Therefore, there are recommendations to pay attention to the cholesterol level in the diet. Nevertheless, the latest research shows that eating even two eggs a day has no adverse health effects $[49,50]$.

During the evaluation of the nutritional value of eggs, not only lipids components levels but also amounts of other nutritional elements should be considered. In this study, the content of iron and zinc was also assessed. The daily reference intakes in the Euro- 
pean Union for these minerals are 14 and $10 \mathrm{mg}$, respectively [51]. $100 \mathrm{~g}$ of the edible part of a hen's egg covers the RDA for iron in 10.4\% (18.3\% of quail eggs) and for zinc in $9.3 \%$ (13.7\% of quail eggs). Our results of iron and zinc are consistent with the studies published by other authors [52-54].

Consumers perceive organic products as richer in nutrients and healthier. Eggs with a lower number on a shell (denoting the production method) are better received [55]. According to the presented results, there are a little (but statistically significant) deviations in the content of tested components between groups. However, based on these results it is not possible to point eggs from the exact production system based on lipid components content or profile (as cluster analysis confirmed). For each tested ingredient in one product group, there was quite a high variation in the results, which could be due to the individual variability, hens age and different feeds used by different producers. Some other authors have drawn similar conclusions [56,57]. Another issue is the welfare of the animals from which eggs are obtained. Nowadays, animal welfare is a significant concern in the consumer's decision about animal products, even if it relates to a higher price and knowledge about no significant differences in nutritional value $[58,59]$.

Due to their very high nutritional value, eggs can be considered a functional food [60]. However, producers wanting to meet consumers demands and competition modify their products. Eggs enriched with vitamins, minerals, and other bioactive ingredients are created [10]. On the polish market, quite common are eggs declared in high content of omega-3 FA. Modification of the egg lipid components profile is usually done by modifying the hens' diet. A series of studies have shown that the addition of ALA-rich linseed to the feed can increase the n3 PUFA content in egg yolk. Alternatively, hens are fed fish oil or microalgae products as a source of long chain n3 PUFA. Modifications of the fatty acid profile of eggs were also obtained by feeding hens with vegetable oils or various seeds (chia, hemp) [61-63].

In the present study to the N3 group was chosen only product with a clear nutrition claim (high in omega-3 FA) on the package. This group of products was distinguished by the content of fatty components compared to others; had the most favourable values of fat quality indices. However, according to the European Commission Regulation No. 1924/2006 (as amended): "A claim that a food is high in omega-3 fatty acids, and any claim likely to have the same meaning for the consumer, may only be made where the product contains at least $0.6 \mathrm{~g} \alpha$-linolenic acid per $100 \mathrm{~g}$ and per $100 \mathrm{kcal}$ or at least $80 \mathrm{mg}$ of the sum of eicosapentaenoic acid and docosahexaenoic acid per $100 \mathrm{~g}$ and per $100 \mathrm{kcal}$ " [64]. Unfortunately, none of the eggs in group N3 achieved the level of $0.6 \mathrm{~g}$ ALA per 100 $\mathrm{g}$ of product or $100 \mathrm{~g}$ of the edible part. Only one producer (out of eight) met the second condition; the sum of EPA and DHA was $95.87 \mathrm{mg} 100 \mathrm{~g}-1$ of the product (average in chicken eggs was $48.00 \mathrm{mg} 100 \mathrm{~g}-1$ ) and $126,02 \mathrm{mg}$ per $100 \mathrm{~g}$ of edible parts (average 55.10 $\mathrm{mg}$ in chicken eggs). The seven producers whose eggs were evaluated in this study should not include a nutrition claim on their packages with an increased n3 PUFA content. Many experiments are confirming the possibility of increasing the n3 PUFA content in eggs [65]. There are also studies of marketed products where the nutrition claim corresponds to an increased amount of these valuable fatty acids [57]. Our research proves that controls on the compatibility of nutrition claims with the real level of the declared nutrients in eggs are necessary.

Another tested premium product are eggs from Green-legged partridge hens. These eggs have gained popularity on the Polish market due to their better sensory quality than traditional products [66]. Consumers may also believe that they have higher nutritional value. Moreover, their price is higher than other products. The parameters of the egg (the whole egg, edible parts, and yolk weight) were slightly lower than in other groups of chicken eggs, which is characteristic feature of this breed [67]. However, the content of fat, fatty acids, cholesterol, iron, and zinc in the yolk did not differ from other groups of chicken eggs. Previous studies have shown that the breed of laying hens affects the nutritional value of eggs $[65,68]$. However, these studies were usually conducted under controlled conditions. However, in the case of market eggs, many factors are affecting the 
final quality of the product, so the differences between breeds can be equalized by other determinants. Only selected parameters of the nutritional quality of eggs were evaluated in this study. Perhaps the differences in the content of other nutrients or bioactive components between eggs from Green-legged partridge hens and traditional products would be significant.

Quail eggs are quite popular in some regions of the world. Their appearance, size, sensory features, and nutritional value are different from chicken eggs, as they are laid by completely different species of birds [69]. In this study, attention should be paid to higher iron and cholesterol content in quail eggs than in chicken eggs. The differences are even more pronounced when converted into $100 \mathrm{~g}$ of whole egg or $100 \mathrm{~g}$ of edible parts. The share of yolk in a quail egg is about $10 \%$ higher than in a hen's egg (38.5 vs $28.1 \%)$. Although the percentage share of the main groups of FA (SFA, MUFA, PUFA) in the total FA content is similar, the content of individual acids distinguishes quail eggs from the other studied groups. The data for quail eggs presented in this study are consistent with the results of studies obtained by other authors [69-71]. Quail eggs seem to be an interesting alternative to chicken eggs in the kitchen.

\section{Conclusions}

Bird eggs are an almost perfect product, intended to provide the bird embryo with all the nutrients necessary for development. Therefore, they also play a significant role in people diet. Compared to other products of animal origin, the fatty acid profile is favourable, and modification of the laying hens' diet may contribute to the increase of the level of $\mathrm{n} 3$ fatty acids, especially valuable EPA and DHA. In this study, no differences in the content of tested nutrients between eggs from different production methods (E, F, B, C), as well as inter-breed differences (GL) were noticed. Quail eggs differed in terms of FA profile, as well as iron and cholesterol levels from chicken eggs. Meals prepared from them can be an interesting alternative to a traditional omelette.

Supplementary Materials: The following are available online at www.mdpi.com/xxx/s1, Figure S1: title, Table S1: title, Video S1: title.

Author Contributions: Conceptualization, M.C and A.B.; Methodology, A.B., M.C. and D.S.; Validation, A.B., M.C. and D.S.; Formal Analysis, A.B., M.C. and D.S.; Investigation, M.C. and A.B.; Resources, M.C and A.B.; Data Curation, M.C.; Writing - Original Draft Preparation, M.C; Writing - Review \& Editing, A.B. and B.B.-K.; Supervision, A.B. and B.B.-K.; Project Administration, B.B.-K. All authors have read and agreed to the published version of the manuscript.

Funding: This research received no external funding

Institutional Review Board Statement: Not applicable.

Informed Consent Statement: Not applicable.

Conflicts of Interest: The authors declare no conflict of interest.

\section{References}

1. Bertechini, A.G. Chapter 21 - Economic and Cultural Aspects of the Table Egg as an Edible Commodity. In Egg Innovations and Strategies for Improvements; Hester, P.Y., Ed.; Academic Press: San Diego, 2017; pp. 223-232 ISBN 978-0-12-800879-9.

2. Pllana, M.; Miftari, I.; Bytyqi, N.; Hyseni, V. The Market of Eggs, Consumption, and Consumer Behavior Available online: www.igi-global.com/article/the-market-of-eggs-consumption-and-consumer-behavior/133268 (accessed on 24 February 2021).

3. Fernandez, M.L. Eggs and Health Special Issue. Nutrients 2016, 8, 784, doi:10.3390/nu8120784.

4. $\quad$ Briggs, M.A.; Petersen, K.S.; Kris-Etherton, P.M. Saturated Fatty Acids and Cardiovascular Disease: Replacements for Saturated Fat to Reduce Cardiovascular Risk. Healthcare 2017, 5, 29, doi:10.3390/healthcare5020029.

5. Shinn, S.E.; Proctor, A.; Baum, J.I. Egg Yolk as Means for Providing Essential and Beneficial Fatty Acids. Journal of the American Oil Chemists' Society 2018, 95, 5-11, doi:https://doi.org/10.1002/aocs.12008.

6. Zaheer, K. An Updated Review on Chicken Eggs: Production, Consumption, Management Aspects and Nutritional Benefits to Human Health. Food and Nutrition Sciences 2015, 06, 1208, doi:10.4236/fns.2015.613127. 
7. Kovacs-Nolan, J.; Phillips, M.; Mine, Y. Advances in the Value of Eggs and Egg Components for Human Health. J. Agric. Food Chem. 2005, 53, 8421-8431, doi:10.1021/jf050964f.

8. Réhault-Godbert, S.; Guyot, N.; Nys, Y. The Golden Egg: Nutritional Value, Bioactivities, and Emerging Benefits for Human Health. Nutrients 2019, 11, 684, doi:10.3390/nu11030684.

9. European Commission Regulation (EC) No 589/2008 of 23 June 2008 Laying down Detailed Rules for Implementing Council Regulation (EC) No 1234/2007 as Regards Marketing Standards for Eggs 2008.

10. Alagawany, M.; Farag, M.R.; Dhama, K.; Patra, A. Nutritional Significance and Health Benefits of Designer Eggs. World's Poultry Science Journal 2018, 74, 317-330, doi:10.1017/S0043933918000041.

11. Folch, J.; Lees, M.; Sloane Stanley, G.H. A Simple Method for the Isolation and Purification of Total Lipides from Animal Tissues. J Biol Chem 1957, 226, 497-509.

12. Bialek, A.; Bialek, M.; Jelinska, M.; Tokarz, A. Fatty Acid Profile of New Promising Unconventional Plant Oils for Cosmetic Use. Int J Cosmet Sci 2016, 38, 382-388, doi:10.1111/ics.12301.

13. Chen, J.; Liu, H. Nutritional Indices for Assessing Fatty Acids: A Mini-Review. International Journal of Molecular Sciences 2020, 21, 5695, doi:10.3390/ijms21165695.

14. Łuczyńska, J.; Paszczyk, B. Health Risk Assessment of Heavy Metals and Lipid Quality Indexes in Freshwater Fish from Lakes of Warmia and Mazury Region, Poland. International Journal of Environmental Research and Public Health 2019, 16, 3780, doi:10.3390/ijerph16193780.

15. Salter, A.M. Dietary Fatty Acids and Cardiovascular Disease. Animal 2013, 7, 163-171, doi:10.1017/S1751731111002023.

16. Fritsche, K.L. The Science of Fatty Acids and Inflammation. Advances in Nutrition 2015, 6, 293S-301S, doi:10.3945/an.114.006940.

17. Neunlist, M.; Schemann, M. Nutrient-Induced Changes in the Phenotype and Function of the Enteric Nervous System. The Journal of Physiology 2014, 592, 2959-2965, doi:https://doi.org/10.1113/jphysiol.2014.272948.

18. Greenfield, H.; Southgate, D. Appendix 5 - Calculations of fatty acids in $100 \mathrm{~g}$ food and $100 \mathrm{~g}$ total fatty acids. In Food composition data. Production, management and use; 2003.

19. Gillingham, L.G.; Harris-Janz, S.; Jones, P.J.H. Dietary Monounsaturated Fatty Acids Are Protective Against Metabolic Syndrome and Cardiovascular Disease Risk Factors. Lipids 2011, 46, 209-228, doi:https://doi.org/10.1007/s11745-010-3524-y.

20. Choque, B.; Catheline, D.; Rioux, V.; Legrand, P. Linoleic Acid: Between Doubts and Certainties. Biochimie 2014, 96, 14-21, doi:10.1016/j.biochi.2013.07.012.

21. Scientific Opinion on the Tolerable Upper Intake Level of Eicosapentaenoic Acid (EPA), Docosahexaenoic Acid (DHA) and Docosapentaenoic Acid (DPA). EFSA Journal 2012, 10, 2815, doi:https://doi.org/10.2903/j.efsa.2012.2815.

22. Ulbricht, T.L.V.; Southgate, D.A.T. Coronary Heart Disease: Seven Dietary Factors. The Lancet 1991, 338, 985-992, doi:10.1016/0140-6736(91)91846-M.

23. Łuczyńska, J.; Paszczyk, B.; Nowosad, J.; Łuczyński, M.J. Mercury, Fatty Acids Content and Lipid Quality Indexes in Muscles of Freshwater and Marine Fish on the Polish Market. Risk Assessment of Fish Consumption. International Journal of Environmental Research and Public Health 2017, 14, 1120, doi:10.3390/ijerph14101120.

24. Fernandes, C.E.; Vasconcelos, M.A. da S.; de Almeida Ribeiro, M.; Sarubbo, L.A.; Andrade, S.A.C.; Filho, A.B. de M. Nutritional and Lipid Profiles in Marine Fish Species from Brazil. Food Chemistry 2014, 160, 67-71, doi:10.1016/j.foodchem.2014.03.055.

25. Bouzgarrou, O.; Mzougui, N.E.; Sadok, S. Smoking and Polyphenols' Addition to Improve Freshwater Mullet (Mugil Cephalus) Fillets' Quality Attributes during Refrigerated Storage. 2016, doi:10.1111/IJFS.12955.

26. Senso, L.; Suarez, M.; Ruiz-Cara, T.; García-Gallego, M. On the Possible Effects of Harvesting Season and Chilled Storage on the Fatty Acid Profile of the Fillet of Farmed Gilthead Sea Bream (Sparus Aurata). Food Chemistry 2007, 101, 298-307, doi:10.1016/j.foodchem.2006.01.036.

27. Bermingham, E.N.; Agnew, M.; Reis, M.G.; Taukiri, K.; Jonker, A.; Cameron-Smith, D.; Craigie, C.R. Assessment of Atherogenic Index, Long-Chain Omega-3 Fatty Acid and Phospholipid Content of Prime Beef: A Survey of Commercially Sourced New Zealand Wagyu and Angus Beef Cattle. Anim. Prod. Sci. 2020, 61, 179-190, doi:10.1071/AN19427.

28. Kasprzyk, A.; Tyra, M.; Babicz, M. Fatty Acid Profile of Pork from a Local and a Commercial Breed. Archives Animal Breeding 2015, 58, 379-385, doi:https://doi.org/10.5194/aab-58-379-2015.

29. Alvarenga, A.L.N.; Sousa, R.V.; Parreira, G.G.; Chiarini-Garcia, H.; Almeida, F.R.C.L. Fatty Acid Profile, Oxidative Stability of Pork Lipids and Meat Quality Indicators Are Not Affected by Birth Weight. Animal 2014, 8, 660-666, doi:10.1017/S1751731114000093.

30. Salvatori, G.; Pantaleo, L.; Di Cesare, C.; Maiorano, G.; Filetti, F.; Oriani, G. Fatty Acid Composition and Cholesterol Content of Muscles as Related to Genotype and Vitamin E Treatment in Crossbred Lambs. Meat Science 2004, 67, 45-55, doi:10.1016/j.meatsci.2003.09.004.

31. Markiewicz-Kęszycka, M.; Czyżak-Runowska, G.; Lipińska, P.; Wójtowski, J. Fatty Acid Profile of Milk - A Review. Bulletin of the Veterinary Institute in Pulawy 2013, 57, 135-139, doi:10.2478/bvip-2013-0026.

32. Nantapo, C.T.W.; Muchenje, V.; Hugo, A. Atherogenicity Index and Health-Related Fatty Acids in Different Stages of Lactation from Friesian, Jersey and Friesian×Jersey Cross Cow Milk under a Pasture-Based Dairy System. Food Chemistry 2014, 146, 127-133, doi:10.1016/j.foodchem.2013.09.009. 
33. Paszczyk, B.; Polak-Śliwińska, M.; Łuczyńska, J. Fatty Acids Profile, Trans Isomers, and Lipid Quality Indices in Smoked and Unsmoked Cheeses and Cheese-Like Products. International Journal of Environmental Research and Public Health 2020, 17, 71, doi:10.3390/ijerph17010071.

34. Paszczyk, B.; Łuczyńska, J. The Comparison of Fatty Acid Composition and Lipid Quality Indices in Hard Cow, Sheep, and Goat Cheeses. Foods 2020, 9, 1667, doi:10.3390/foods9111667.

35. Vargas-Bello-Pérez, E.; Vera, R.R.; Aguilar, C.; Lira, R.; Peña, I.; Fernández, J. Feeding Olive Cake to Ewes Improves Fatty Acid Profile of Milk and Cheese. Animal Feed Science and Technology 2013, 184, 94-99, doi:10.1016/j.anifeedsci.2013.05.016.

36. Ying, Q.; Wojciechowska, P.; Siger, A.; Kaczmarek, A.; Rudzińska, M. Phytochemical Content, Oxidative Stability, and Nutritional Properties of Unconventional Cold-Pressed Edible Oils. Journal of Food and Nutrition Research 2018, 6, 476-485, doi:10.12691/jfnr-6-7-9.

37. Tonial, I.; Oliveira, D.; Coelho, A.; Matsushita, M.; Coró, F.; Souza, N. de; Visentainer, J. Quantification of Essential Fatty Acids and Assessment of the Nutritional Quality Indexes of Lipids in Tilapia Alevins and Juvenile Tilapia Fish (Oreochromis Niloticus). Journal of Food Research 2014, 3, p105, doi:10.5539/jfr.v3n3p105.

38. Cebulska, A.; Václavková, E.; Bocian, M.; Dybała, J.; Wiśniewska, J.; Kapelański, W. Quality and Dietary Value of Pork Meat of the Puławska and Złotnicka Spotted Breeds, and Commercial Fattening Pigs. Annals of Animal Science 2018, 18, 281-291, doi:10.1515/aoas-2017-0033.

39. Pires, M.A.; Rodrigues, I.; Barros, J.C.; Carnauba, G.; Carvalho, F.A. de; Trindade, M.A. Partial Replacement of Pork Fat by Echium Oil in Reduced Sodium Bologna Sausages: Technological, Nutritional and Stability Implications. Journal of the Science of Food and Agriculture 2020, 100, 410-420, doi:https://doi.org/10.1002/jsfa.10070.

40. Santos-Silva, J.; Bessa, R.J.B.; Santos-Silva, F. Effect of Genotype, Feeding System and Slaughter Weight on the Quality of Light Lambs: II. Fatty Acid Composition of Meat. Livestock Production Science 2002, 77, 187-194, doi:10.1016/S0301-6226(02)00059-3.

41. Fernández, M.; Ordóñez, J.A.; Cambero, I.; Santos, C.; Pin, C.; Hoz, L. de la Fatty Acid Compositions of Selected Varieties of Spanish Dry Ham Related to Their Nutritional Implications. Food Chemistry 2007, 101, 107-112, doi:10.1016/j.foodchem.2006.01.006.

42. Wójciak, K.M.; Stasiak, D.M.; Ferysiuk, K.; Solska, E. The Influence of Sonication on the Oxidative Stability and Nutritional Value of Organic Dry-Fermented Beef. Meat Sci 2019, 148, 113-119, doi:10.1016/j.meatsci.2018.10.010.

43. Ahmad, N.; Shabbir, U.; Sameen, A.; Manzoor, M.F.; Ahmad, M.H.; Ismail, T.; Ahmed, S.; Siddique, R.; Ahmad, N.; Shabbir, U.; et al. Hypocholesterolemic Effect of Designer Yogurts Fortified with Omega Fatty Acids and Dietary Fibers in Hypercholesterolemic Subjects. Food Science and Technology 2021, doi:10.1590/fst.22420.

44. Guimarães, R. de C.A.; Macedo, M.L.R.; Munhoz, C.L.; Filiu, W.; Viana, L.H.; Nozaki, V.T.; Hiane, P.A. Sesame and Flaxseed Oil: Nutritional Quality and Effects on Serum Lipids and Glucose in Rats. Food Science and Technology 2013, 33, 209-217, doi:10.1590/S0101-20612013005000029.

45. Rokosik, E.; Dwiecki, K.; Siger, A. Nutritional Quality and Phytochemical Contents of Cold Pressed Oil Obtained from Chia, Milk Thistle, Nigella, and White and Black Poppy Seeds. grasasaceites 2020, 71, e368-e368, doi:10.3989/gya.0679191.

46. Blesso, C.N.; Fernandez, M.L. Dietary Cholesterol, Serum Lipids, and Heart Disease: Are Eggs Working for or Against You? Nutrients 2018, 10, 426, doi:10.3390/nu10040426.

47. Brown, A.J.; Jessup, W. Oxysterols: Sources, Cellular Storage and Metabolism, and New Insights into Their Roles in Cholesterol Homeostasis. Molecular Aspects of Medicine 2009, 30, 111-122, doi:10.1016/j.mam.2009.02.005.

48. Brzeska, M.; Szymczyk, K.; Szterk, A. Current Knowledge about Oxysterols: A Review. Journal of Food Science 2016, 81, R2299-R2308, doi:https://doi.org/10.1111/1750-3841.13423.

49. Alexander, D.D.; Miller, P.E.; Vargas, A.J.; Weed, D.L.; Cohen, S.S. Meta-Analysis of Egg Consumption and Risk of Coronary Heart Disease and Stroke. Journal of the American College of Nutrition 2016, 35, 704-716, doi:10.1080/07315724.2016.1152928.

50. Missimer, A.; DiMarco, D.M.; Andersen, C.J.; Murillo, A.G.; Vergara-Jimenez, M.; Fernandez, M.L. Consuming Two Eggs per Day, as Compared to an Oatmeal Breakfast, Decreases Plasma Ghrelin While Maintaining the LDL/HDL Ratio. Nutrients 2017, 9, 89, doi:10.3390/nu9020089.

51. European Commission Regulation (EC) No 1169/2011 of the European Parliament and of the Council of 25 October 2011 on the Provision of Food Information to Consumers 2011.

52. Ruxton, C.; Derbyshire, E.; Gibson, S. The Nutritional Properties and Health Benefits of Eggs. Nutrition \& Food Science 2010, 40, 263-279, doi:10.1108/00346651011043961.

53. Skřivan, M.; Skřivanová, V.; Marounek, M. Effects of Dietary Zinc, Iron, and Copper in Layer Feed on Distribution of These Elements in Eggs, Liver, Excreta, Soil, and Herbage. Poultry Science 2005, 84, 1570-1575, doi:10.1093/ps/84.10.1570.

54. Rubio, C.; Paz, S.; Ojeda, I.; Gutiérrez, A.J.; González-Weller, D.; Hardisson, A.; Revert, C. Dietary Intake of Metals from Fresh Cage-Reared Hens' Eggs in Tenerife, Canary Islands Available online: https://www.hindawi.com/journals/jfq/2017/5972153/ (accessed on 2 March 2021).

55. Rondoni, A.; Asioli, D.; Millan, E. Consumer Behaviour, Perceptions, and Preferences towards Eggs: A Review of the Literature and Discussion of Industry Implications. Trends in Food Science \& Technology 2020, 106, 391-401, doi:10.1016/j.tifs.2020.10.038. 
56. Yenice, G.; Kaynar, O.; Ileriturk, M.; Hira, F.; Hayirli, A. Quality of Eggs in Different Production Systems. Czech Journal of Food Sciences 2016, 34 (2016), 370-376, doi:10.17221/33/2016-CJFS.

57. Samman, S.; Kung, F.P.; Carter, L.M.; Foster, M.J.; Ahmad, Z.I.; Phuyal, J.L.; Petocz, P. Fatty Acid Composition of Certified Organic, Conventional and Omega-3 Eggs. Food Chemistry 2009, 116, 911-914, doi:10.1016/j.foodchem.2009.03.046.

58. Żakowska-Biemans, S.; Tekień, A. Free Range, Organic? Polish Consumers Preferences Regarding Information on Farming System and Nutritional Enhancement of Eggs: A Discrete Choice Based Experiment. Sustainability 2017, 9, 1999, doi:10.3390/su9111999.

59. Cao, Y. (Jessica); Cranfield, J.; Chen, C.; Widowski, T. Heterogeneous Informational and Attitudinal Impacts on Consumer Preferences for Eggs from Welfare Enhanced Cage Systems. Food Policy 2020, 101979, doi:10.1016/j.foodpol.2020.101979.

60. Miranda, J.M.; Anton, X.; Redondo-Valbuena, C.; Roca-Saavedra, P.; Rodriguez, J.A.; Lamas, A.; Franco, C.M.; Cepeda, A. Egg and Egg-Derived Foods: Effects on Human Health and Use as Functional Foods. Nutrients 2015, 7, 706-729, doi:10.3390/nu7010706.

61. Oliveira, D.D.; Baião, N.C.; Cançado, S.V.; Grimaldi, R.; Souza, M.R.; Lara, L.J.C.; Lana, A.M.Q. Effects of Lipid Sources in the Diet of Laying Hens on the Fatty Acid Profiles of Egg Yolks1. Poultry Science 2010, 89, 2484-2490, doi:10.3382/ps.2009-00522.

62. Omidi, M.; Rahimi, S.; Karimi Torshizi, M.A. Modification of Egg Yolk Fatty Acids Profile by Using Different Oil Sources. Vet Res Forum 2015, 6, 137-141.

63. Fraeye, I.; Bruneel, C.; Lemahieu, C.; Buyse, J.; Muylaert, K.; Foubert, I. Dietary Enrichment of Eggs with Omega-3 Fatty Acids: A Review. Food Research International 2012, 48, 961-969, doi:10.1016/j.foodres.2012.03.014.

64. European Commission Regulation (EC) No 1924/2006 of the European Parliament and of the Council of 20 December 2006 on Nutrition and Health Claims Made on Foods (as Amended) 2006.

65. Lordelo, M.; Fernandes, E.; Bessa, R.J.B.; Alves, S.P. Quality of Eggs from Different Laying Hen Production Systems, from Indigenous Breeds and Specialty Eggs. Poultry Science 2017, 96, 1485-1491, doi:10.3382/ps/pew409.

66. Biesiada-Drzazga, B.; Banaszewska, D.; Andraszek, K.; Bombik, E.; Kałuża, H.; Rojek, A. Comparison of Egg Quality of Free Range Araucana and Green-Legged Partridge Chickens. European Poultry Science 2014, 78, doi:10.1399/eps.2014.36.

67. Sokołowicz, Z.; Dykiel, M.; Krawczyk, J.; Augustyńska-Prejsnar, A. Effect of Layer Genotype on Physical Characteristics and Nutritive Value of Organic Eggs. CyTA - Journal of Food 2019, 17, 11-19, doi:10.1080/19476337.2018.1541480.

68. Sirri, F.; Zampiga, M.; Soglia, F.; Meluzzi, A.; Cavani, C.; Petracci, M. Quality Characterization of Eggs from Romagnola Hens, an Italian Local Breed. Poultry Science 2018, 97, 4131-4136, doi:10.3382/ps/pey275.

69. Arthur, J.; Bejaei, M. Chapter 2 - Quail Eggs. In Egg Innovations and Strategies for Improvements; Hester, P.Y., Ed.; Academic Press: San Diego, 2017; pp. 13-21 ISBN 978-0-12-800879-9.

70. Golzar Adabi, S. Enrichment of Quail (Coturnix Cot. Japonica) Eggs by Omega-3 Fatty Acids and Its Nutritional Effect on Young Healthy Women. Europ.Poult.Sci. 2016, 80, doi:10.1399/eps.2016.149.

71. Tolik, D.; Poawska, E.; Charuta, A.; Nowaczewski, S.; Cooper, R. Characteristics of Egg Parts, Chemical Composition and Nutritive Value of Japanese Quail Eggs - a Review. Folia Biologica 2014, 62, 287-292, doi:10.3409/fb62_4.287. 